\title{
ANALISIS PEMBERDAYAAN PSIKOLOGIS TERHADAP KREATIVITAS DOSEN FAKULTAS PERTANIAN UNIVERSITAS SYIAH KUALA DENGAN MOTIVASI INTRINSIK SEBAGAI VARIABEL PEMEDIASI
}

\author{
Amsal Irmalis ${ }^{1}$ Anas $^{2}$ \\ ${ }^{1}$ Universitas Teuku Umar \\ amsalamsal15@gmail.com \\ ${ }^{2}$ Universitas Syiah Kuala \\ anas.eoc@gmail.com
}

\begin{abstract}
ABSTRAK
Penelitian ini bertujuan untuk mengetahui pengaruh pemberdayaan psikologis terhadap motivasi intrinsic dan dampaknya terhadap kreatifitas. Sampel yang digunakan dalam penelitian ini adalah dosen fakultas pertanian universitas syiah kuala yang berjumlah 61 responden. Metode penelitian ini menggunakan kuesioner sebagai instrument penelitian. Tehnik sampel yang digunakan adalah probability sampling. Teknik pengambilan jumlah sampel populasinya menggunakan prosedur acak berstrata. Metode analisis Hierarchical Linear Modeling (HLM) digunakan sebagai metode analisis untuk mengetahui pengaruh dari variabel-variabel yang terlibat. Hasil penelitian ini menunjukkan bahwa Pemberdayaan Psikologis berpengaruh terhadap kreativitas, Pemberdayaan Psikologis berpengaruh terhadap Motivasi Mntrinsic, Motivasi Intrinsik berpengaruh terhadap Kreativitas dan Motivasi Intrinsik memediasi secara sempurna (full/perfect mediation) pengaruh Pemberdayaan Psikologis terhadap Kreativitas.
\end{abstract}

Kata kunci: PemberdayaanPsikologis, Motivasi Intrinsik, Kreatifitas

\section{Background}

Pendidikan memiliki peran yang sangat penting dalam mencerdaskan kehidupan bangsa, Perkembangan zaman saat ini menuntut adanya sumber daya manusia yang berkualitas supaya mampu bersaing dengan negara lain yang telah maju. Pendidikan memiliki andil dalam menciptakan sumber daya manusia yang berkualitas. Pendidikan yang berkualiats akan berpengaruh pada kemajuan diberbagai bidang. Pendidikan merupakan salah satu sektor yang paling penting dalam mewujudkan pembangunan nasional.

Tenaga pengajar menjadi faktor utama yang mempengaruhi terwujudnya cita-cita bangsa Indonesia menjadi bangsa yang cerdas sebagaimana tertuang dalam Undang-Undang No. 20 Tahun 2003 Bab II Pasal 3 bahwa Pendidkan nasional berfungsi mengembangkan kemampuan dan membentuk watak seperti peradaban bangsa yang bermartabat dalam rangka mencerdaskan kehidupan bangsa, bertujuan untuk berkembangnya potensi peserta didik agar menjadi manusia yang beriman dan bertaqwa kepada Tuhan Yang Maha Esa, berakhlak mulia, 


\section{Jurnal Bisnis dan Kajian Strategi Manajemen}

\section{Volume 2 Nomor 2, 2018}

ISSN : 2614-2147

http:/ jurnal.utu.ac.id/jbkan

sehat, berilmu, cakap, kreatif, mandiri, menjadi warga negara yang demokratis serta bertanggung jawab.

Dosen adalah salah satu komponen esensial dalam suatu sistem pendidikan di perguruan tinggi. Peran, tugas, dan tanggungjawab dosen sangat penting dalam mewujudkan tujuan pendidikan nasional, yaitu mencerdaskan kehidupan bangsa, meningkatkan kualitas manusia Indonesia, yang meliputi kualitas iman/takwa, akhlak mulia, dan penguasaan ilmu pengetahuan, teknologi, dan seni, serta mewujudkan masyarakat Indonesia yang maju, adil, makmur, dan beradab. Untuk melaksanakan fungsi, peran, dan kedudukan yang sangat strategis tersebut, diperlukan dosen yang profesional.

Sebagaimana diamanatkan dalam UU Nomor 14 Tahun 2005 tentang Guru dan Dosen, dosen dinyatakan sebagai pendidik profesional dan ilmuwan dengan tugas utama mentransformasikan, mengembangkan, dan menyebarluaskan ilmu pengetahuan, teknologi, dan seni melalui pendidikan, penelitian, dan pengabdian kepada masyarakat (Bab 1 Pasal 1 ayat 2). Sementara itu, profesional dinyatakan sebagai pekerjaan atau kegiatan yang dilakukan oleh seseorang dan menjadi sumber penghasilan kehidupan yang memerlukan keahlian, kemahiran, atau kecakapan yang memenuhi standar mutu atau norma tertentu serta memerlukan pendidikan profesi.

Kompetensi tenaga pendidik, khususnya dosen, diartikan sebagai seperangkat pengetahuan, keterampilan dan perilaku yang harus dimiliki, dihayati, dikuasai dan diwujudkan oleh dosen dalam melaksanakan tugas profesionalnya. Kompetensi tersebut meliputi kompetensi pedagogik, kompetensi kepribadian, kompetensi sosial dan kompetensi profesional.

Kompetensi dosen menentukan kuwalitas pelaksanaan Tridharma Perguruan Tinggi sebagaimana yang ditunjukkan dalam kegiatan profesional dosen. Untuk menjamin pelaksanaan tugas dosen berjalan sesuai dengan kriteria yang ditetapkan dalam peraturan.

Untuk menunjang pelaksanaan tridharma perguruan tinggi setiap dosen juga dituntut kreatif. Banyak bukti yang menunjukkan bahwa kreativitas memiliki kontribusi fundamental bagi inovasi, efektivitas, dan kelangsungan hidup organisasi (Amabile, 1996). Untuk mewujudkan kreativitas tersebut maka para dosen perlu diberdayakan

Pemberdayaan menjadi salah satu cara untuk meningkatkan kreatifitas, Menurut Kamus Besar Bahasa Indoneasia pemberdayaan secara etimologis berasal dari kata daya yang berarti kemampuan untuk melakukan sesuatu atau kemampuan bertindak. Mendapat awalan ber- menjadi 'berdaya' artinya berkekuatan, berkemampuan, bertenaga, mempunyai akal (cara dan sebagainya) untuk mengatasi sesuatu. Mendapat awalan dan akhiran pe-an sehingga menjadi pemberdayaan yang dapat diartikan sebagai usaha/proses menjadikan untuk membuat mampu, membuat dapat bertindak atau melakukan sesuatu. Sedangkan menurut Kamus Manajemen (Mutu) (Sugian, 2006) menyatakan bahwa "Empowerment (pemberdayaan) adalah kondisi dimana para pekerja memiliki otoritas untuk membuat keputusan dan mengambil tindakan dalam area kerjanya tanpa meminta persetujuan sebelumnya".

Pengertian singkat mengenai pemberdayaan SDM diungkapkan oleh Smith yang menyatakan bahwa memberdayakan orang berarti mendorong mereka menjadi lebih terlibat dalam keputusan dan aktivitas yang memengaruhi pekerjaan mereka. (Wibowo, 2007). 


\section{Jurnal Bisnis dan Kajian Strategi Manajemen}

\section{Volume 2 Nomor 2, 2018}

ISSN : 2614-2147

http://jurnal.utu.ac.id/jbkan

Salah satu bentuk dari pemberdayaan tersebut adalah Pemberdayaan secara Psikologis. Secara umum Pemberdayaan psikologis merupakan bentuk pemberdayaan dimana psikologis ataupun kejiwaan seseorang yang menjadi sasaran pemberdayaan, seseorang diberdayakan secara psikologis untuk menumbuhkan keyakinan serta membangkitkan kemampuan yang dimiliki oleh orang tersebut. Menurut Meyerson (2008) pemberdayaan psikologis adalah keyakinan seorang individu akan kemampuannya untuk melakukan kegiatan kerja terkait denganketerampilan dan kompetensi. (Spreitzer;1998) menyatakan Pemberdayaan psikologis merupakan suatu konsep psikologis yang memiliki beberapa dimensi yaitu meaning, perceived impact, competence, dan self-determination .Keempat dimensi itu tergabung membentuk keseluruhan konstruk pemberdayaan psikologis, atau dengan kata lain, apabila salah satu dimensi tidak ada, maka tingkat pemberdayaan yang diperoleh juga tidak maksimal, Meaning diartikan nilai intrinsik dari suatu tugas kerja seorang karyawan, nilai tersebut dianggap dalam hubungannya dengan tujuan atau standar yang bersangkutan. Perceived impact atau dapat diartikan suatu persepsi tentang seberapa besar pengaruh seseorang berkaitan dengan peran mereka dalam pekerjaan baik dalam hal yang bersifat operasional, strategik maupun administratif. Competence atau kompetensi dapat diartikan sebagai keyakinan seseorang terhadap kemampuannya untuk mengerjakan pekerjaan. Sedangkan self-determination adalah perasaan seseorang berkaitan dengan pilihan dalam mengawali atau mengatur tindakan.

Studi di bidang manajemen juga memperlihatkan bahwa sumberdaya manusia yang telah merasa diberdayakan akan mempunyai tingkat kreativitas yang lebih tinggi. Selanjutnya, tingkat kreatifitas yang tinggi akan memperngaruhi kinerja serta efektivitas dalam penyelesaian tugas-tugas mereka di tempat mereka bekerja. Dosen yang mempunyai kreativitas tinggi menjadi salah satu factor penting dari kesuksesan jangka panjang sebuah perguruan tinggi. Pemberdayaan terhadap dosen menjadi salah satu cara untuk meningkatkan kreativitas.

Pemberdayaan psikologis merangsang motivasi intrinsik yang dimiliki oleh seseorang, Menurut Amabile (1983) motivasi intrinsik adalah salah satu faktor yang pengaruhnya paling penting dan kuat terhadap kreativitas seseorang. Pemberdayaan menjadi sebuah upaya untuk meningkatkan motivasi intrinsik yang mana melibatkan kondisi umum dari seorang individu berkaitan langsung dengan tugas, yang dapat menciptakan motivasi dan kepuasan. Pada teori dua faktor Herzberg dapat diketahui bahwa ternyata gaji yang tinggi, adanya fasilitas yang memadai maupun kondisi kerja yang baik (motivasi ekstrinsik) tidak sepenuhnya dapat meningkatkan motivasi karyawan. Tetapi menurut Herzberg, hanya pekerjaan yang menantang yang mempunyai suatu kesempatan untuk menunjukkan prestasi, tanggung jawab, kemajuan, dan pertumbuhan yang akan memotivasi seseorang. Dapat dikatakan bahwa sebenarnya motif sebenarnya yang dapat meningkatkan motivasi seseorang adalah perasaan tanggung jawab, pencapaian, prestasi (motivasi intrinsic). Apabila seseorang menganggap pekerjaannya mempunyai nilai yang penting (meaning) bagi dirinya, maka motivasi untuk bekerja akan meningkat. Dengan semakin besar pengaruh (impact) yang dapat diberikan oleh seseorang pada pekerjaannya maka perannya untuk pekerjaan besar dan motivasi intrisik akan meningkat dengan semakin besar tanggung jawab yang dipegangnya. Sedangkan kompetensi (competence) seseorang meningkat maka akan secara mudah mencapai prestasi dan pencapaian yang diinginkan. Pada akhirnya dengan adanya kebebasan untuk menentukan sikap terhadap pekerjaannya (self-determination), akan menyebabkan seseorang merasa bebas untuk menentukan langkah yang akan diambil untuk menyelesaikan pekerjaan tersebut. Seseorang akan merasa lebih tertantang untuk menyelesaikan pekerjaan tersebut sendiri tanpa campur tangan orang lain. 


\section{Jurnal Bisnis dan Kajian Strategi Manajemen}

\section{Volume 2 Nomor 2, 2018}

ISSN : 2614-2147

http://jurnal.utu.ac.id/jbkan

Motivasi instrinsik saja tidak cukup untuk meningkatkan kreatifitas. Terlibat dalam proses kreatif memiliki pengaruh yang sama dan tak kalah pentingnya, dalam meningkatkan kreativitas SDM. keterlibatan proses kreatif didefinisikan sebagai keterlibatan karyawan dalam proses kognitif kreativitas yang relevan, termasuk (1) identifikasi masalah , (2) mencari informasi (3) menciptakan ide dan alternatif sebagai solusi (Amabile, 1983). Solusi sederhana yang tidak berguna mungkin muncul ketika individu kurang terlibat dalam proses penyelesaian masalah. Di sisi lain, ketika seseorang menghabiskan upaya untuk lebih mengidentifikasi masalah, memperoleh informasi sebanyak mungkin, dan menghasilkan banyak gagasan dan alternatif, solusi yang baik dan berguna lebih mungkin untuk diproduksi. Garis penalaran ini sama dan sebangun dengan temuan penelitian bahwa ide-ide pertama yang dihasilkan cenderung rutin dan kurang kreatif, sedangkan ide yang diidentifikasi kemudian dalam proses generasi ide cenderung lebih kreatif (Runco, 2004).

Melihat dari sisi Pemberdayaan psikologis yang pernah didapatkan dosen di fakultas pertanian untuk merangsang kreatifitas yang mereka miliki, seperti diberii kepercayaan untuk meenyelesaikan tugas,diberi keleluasaan dalam bertindak, meyakinkan dosen tersebut mengenai kemampuan yang mereka milik hal ini bisa dikatakan masih belum menyeluruh. Dengan karakteristik dari pemberdayaan psikologis itu sendiri yang bersifat intens memungkinkan terjadinya ketidakmerataan dalam upaya melakukan pemberdayaan psikologis tersebut.

\section{Tinjauan Pustaka}

Munandar (1999) menjelaskan dalam melakukan kegiatan yang kreatif, sedikit banyak orang yang berpikir kreatif melihat dan memikirkan hal-hal yang luar biasa yang tidak lazim. Dalam teorinya, Munandar menjelaskan bahwa kreativitas juga memadukan informasi yang tampaknya tidak berhubungan dan mencetuskan solusi-solusi baru yang memiliki karakteristik sebagai berikut:

1. Rasa ingin tahu

Individu selalu terdorong untuk mengetahui lebih banyak dan mengajukan banyak pertanyaan. Selalu memperhatikan orang, obyek dan situasi sehingga peka dalam pengamatan dan ingin mengetahui/meneliti.

2. Bersifat Imaginative

Individu mampu memperagakan atau mebayangkan hal-hal yang tidak atau belum pernah terjadi. Namun, dalam menggunakan khayalan tersebut masih dapat mengetahui perbedaan antara khayalan dan kenyataan.

3. Merasa tertantang oleh kemajemukan

Individu terdorong untuk mengatasi masalah yang sulit. Merasa tertantang oleh situasi-situasi yang rumit sehingga lebih tertarik pada tugas yang sulit.

4. Sifat menghargai

Dapat menghargai bimbingan dan pengarahan dalam hidup. Menghargai kemampuan dan bakat-bakat sendiri yang sedang berkembang.

5. Berani mengambil resiko

Berani memberikan jawaban meskipun belum tentu benar. Tidak takut gagal atau mendapat kritik. Tidak menjadi ragu-ragu karena ketidakjelasan, hal-hal yang tidak konvensional, atau yang tidak berstruktur. 


\section{Jurnal Bisnis dan Kajian Strategi Manajemen}

\section{Volume 2 Nomor 2, 2018}

ISSN : 2614-2147

http://jurnal.utu.ac.id/jbkan

Sedangkan menurut Chandra (1994), terdapat sepuluh karakteristik orang kreatif, yaitu:

1. Hasrat, mengubah hal-hal yang disekitasnya menjadi lebih baik.

2. Kepekaan, bersikap terbuka dan tanggap terhadap segala sesuatu.

3. Minat, mengenal lebih dalam dari yang tampak dipermukaan.

4. Rasa ingin tahu, semangat yang tak pernah pendek untuk menanyakan.

5. Mendalam dalam berpikir, sikap yang mengarah untuk pemahaman yang mendalam pula.

6. Konsentrasi, mampu menekuni suatu permasalahan hingga menguasai seluruh bagiannya.

7. Siap mencoba dan melaksanakannya, bersedia mencurahkan tenaga dan waktu untuk mencari dan mengembangkan.

8. Kesabaran, untuk memecahkan masalah dalam detailnya.

9. Optimisme, memadukan antusiasme dan rasa percaya diri.

10. Mampu bekerja sama, mampu bekerja keras secara produktif dengan orang lain.

Selain itu menurut Amabile (1983), dalam menentukan karakteristik kreativitas sehingga seseorang layak dikatakan sebagai individu yang kreatif, maka ada tiga dimensi yang mampu menunjukan kriteria tersebut, adapun dimensi yang dimaksud yaitu dimensi proses, orang atau pribadi, dan produk kreatif.

Kriteria yang pertama dengan menggunakan proses kreatif sebagai kriteria kreativitas, maka segala produk yang dihasilkan dari proses itu dianggap sebagai produk kreatif, dan orangnya disebut sebagai orang kreatif. Menurut Rothernberg (1976) proses kreatif identik dengan berpikir Janusian, yaitu suatu tipe berpikir divergen yang berusaha melihat berbagai dimensi yang beragam atau bahkan bertentangan menjadi suatu pemikiran yang baru.

Kemudian kriteria yang kedua dimensi orang atau pribadi sebagai kriteria kreativitas seringkali kurang jelas rumusannya. Amabile (1983) mengatakan bahwa pengertian orang atau pribadi sebagai kriteria kreativitas identik dengan yang dikemukakan Guilford (1950) disebut kepribadian kreatif. Kepribadian kreatif menurut Guilford meliputi dimensi kognitif (yaitu bakat) dan non-kognitif (yaitu minat, sikap, dan kualitas temperamental). Menurut teori ini, orang-orang kreatif memiliki ciri-ciri kepribadian yang yang secara signifikan berbeda dengan orang-orang yang kurang kreatif. Karakteristik-karakteristik kepribadian ini menjadi kriteria untuk mengidentifikasi orang-orang kreatif menurut Guilford (dalam Munandar, 2009) criteria tersebut antara lain:

a. Kelancaran berpikir (fluency of thinking), yaitu kemampuan untuk menghasilkan banyak ide yang keluar dari pemikiran seseorang secara cepat. Dalam kelancaran berpikir, yang ditekankan adalah kuantitas, dan bukan kualitas.

b. Keluwesan berpikir (flexibility), yaitu kemampuan untuk memproduksi sejumlah ide, jawaban-jawaban atau pertanyaan-pertanyaan yang bervariasi, dapat melihat suatu masalah dari sudut pandang yang berbeda-beda, mencari alternatif atau arah yang berbeda-beda, serta mampu menggunakan bermacam-macam pendekatan atau cara pemikiran. Orang yang kreatif adalah orang yang luwes dalam berpikir. Mereka dengan mudah dapat meninggalkan cara berpikir lama dan menggantikannya dengan cara berpikir yang baru.

c. Elaborasi (elaboration), yaitu kemampuan dalam mengembangkan gagasan dan menambahkan atau memperinci detail-detail dari suatu objek, gagasan atau situasi sehingga menjadi lebih menarik. 


\section{Jurnal Bisnis dan Kajian Strategi Manajemen}

\section{Volume 2 Nomor 2, 2018}

ISSN : 2614-2147

http://jurnal.utu.ac.id/jbkan

d. Originalitas (originality), yaitu kemampuan untuk mencetuskan gagasan unik atau kemampuan untuk mencetuskan gagasan asli.

Orang-orang yang memiliki ciri-ciri seperti yang dimiliki oleh orang-orang kreatif dengan sendirinya adalah orang kreatif (Supriadi, 1994:13). Kriteria ketiga adalah produk kreatif, yang menunjuk kepada hasil perbuatan, kinerja, atau karya seseorang dalam dalam bentuk barang, atau gagasan. Kriteria ini dipandang sebagai yang paling eksplisit untuk menentukan kreativitas seseorang, sehingga disebut sebagai 'kriteria puncak" bagi kreativitas (Amabile, 1983). Dalam operasi penilaiannya, proses identifikasi kreativitas dilakukan melalui analisis obyektif terhadap produk, pertimbangan subyektif oleh peneliti, atau peneliti ahli, dan melalui tes (Supriadi, 1994: 14). Dari kajian tentang kreativitas di atas, penulis lebih terfokus pada produk kreatif. Karena produk kreatif lebih dapat diamati, dan apapun fokus kreativitas pada akhirnya penilaian terhadap seseorang tentang kreativitas adalah produk orang tersebut, apakah orang tersebut mempunyai produk yang kreatif atau tidak. Tanpa itu tidak mungkin seseorang dapat dikatakan kreatif, atau mempunyai kreativitas yang tinggi.

Berdasarkan karakteristik yang dikemukakan diatas maka dapat disimpulkan bahwa karakteristik orang yang kreatif adalah individu yang memiliki hasrat keingintahuan, minat dan kepekaan yang besar, berani mengambil resiko serta siap mencoba melakukannya, sifat imaginatif, menyukai hal yang rumit dan baru, sabar dalam memecahkan permasalahan sehingga dapat berkonsentrasi terhadap masalah tersebut, dan menghargai orang lain. Memiliki kemampuan menghasilkan ide-ide, keluwesan dan kemampuan ungtuk mengembangkan gagasan serta konsep pemikiranya itu original. Berdasarkan teori diatas peneliti memilih teori Amabile karena teori nya lebih spesifik dan terperinci dan telah mewakili teori-teori dari para tokoh yang lain.

Sebelum menjelaskan tentang pemberdayaan psikologis, peneliti akan memberikan uraian penjelasan tentang definisi pemberdayaan. Pemberdayaan merupakan pelibatan karyawan yang benar-benar berarti. Pemberdayaan atau (empowerment) adalah wewenang untuk membuat keputusan dalam suatu area kegiatan operasi tertentu tanpa harus memperoleh pengesahan orang lain (Luthans, 1998). Sedangkan Straub (dalam Sadarusman, 2004), mengartikan pemberdayaan sebagai pemberian otonomi, wewenang, kepercayaan, dan mendorong individu dalam suatu organisasi untuk mengembangkan peraturan dalam rangka menyelesaikan pekerjaan. Pemberdayaan merupakan pemberian tanggung jawab dan wewenang terhadap pekerja untuk mengambil keputusan menyangkut semua pengembangan produk dan pengambilan keputusan. Pemberdayaan juga berarti saling berbagi informasi dan pengetahuan diantara karyawan yang digunakan untuk memahami dan mendukung kinerja organisasi, pemberian penghargaan terhadap kinerja organisasi dan pemberian otonomi dalam pengambilan keputusan yang berpengaruh terhadap organisasi.

Conger dan Kanungo (1988) mendefinisikan pemberdayaan psikologis sebagai proses meningkatkan perasaan karyawan self-efficacy melalui identifikasi kondisi yang memupuk keberdayaan dan melalui penghapusan mereka dengan kedua praktek organisasi formal dan teknik informal menyediakan informasi kemanjuran.

Pemberdayaan psikologis, didefinisikan sebagai keadaan psikologis yang dimanifestasikan dalam empat kognisi: arti , kompetensi, penentuan nasib sendiri, dan dampak (Spreitzer, 1995). Dengan demikian kita dieksplorasi sejauh mana pemberdayaan karya kepemimpinan melalui pemberdayaan psikologis untuk akhirnya mempengaruhi kreativitas karyawan. Argumentasi teoritis telah menyarankan bahwa pemberdayaan psikologis, pada 


\section{Jurnal Bisnis dan Kajian Strategi Manajemen}

Volume 2 Nomor 2, 2018

ISSN : 2614-2147

http://jurnal.utu.ac.id/jbkan

gilirannya, membuat kontribusi penting untuk kreativitas karyawan dengan positif mempengaruhi motivasi intrinsik karyawan, tapi bukti empiris dari efek seperti itu telah kurang, koneksi ini penting karena, secara konseptual, motivasi intrinsik dianggap menjadi prediktor mapan kreativitas (Amabile, 1996; Shalley et al. 2004).

Para peneliti dan praktisi organisasi telah mengidentifikasikan pemberdayaan psikologis sebagai konstruk yang perlu memperoleh perhatian khusus. Meluasnya minat terhadap masalah pemberdayaan psikologis muncul pada saat persaingan global dan perubahan organisasi marak terjadi sehingga organisasi mengharuskan anggotanya lebih inisiatif dan inovatif (Spreitzer, 1995). Menurut Meyerson (2008) pemberdayaan psikologis adalah keyakinan seorang individu akan kemampuannya untuk melakukan kegiatan kerja terkait denganketerampilan dan kompetensi. Lebih jauh Meyerson menjelaskan bahwa pemberdayaan psikologis berkaitan dengan bagaimana orang-orang yang kompeten atau mampu merasa diberdayakan di lingkungan kerjanya. Mereka yang merasa lebih kompeten tentang kemampuan mereka dan berhasil diberdayakan atau memiliki tingkat pemberdayaan psikologis lebih tinggi seharusnya akan:
a. merasa lebih puas dengan pekerjaan mereka
b. akan lebih berkomitmen untuk organisasi mereka
c. memiliki niat yang lebih rendah untuk berhenti berorganisasi
d. menunjukkan kinerja yang lebih positif.

\section{Metodelogi}

Penelitian ini menggunakan analisis pada level individual, sehingga populasi penelitian ini adalah dosen Fakultas Pertanian Universitas Syiah Kuala yang berjumlah 202 orang. Populasi merupakan jumlah keseluruhan elemen yang akan diteliti (Cooper dan Schindler, 2006). Namun, penelitian ini tidak menggunakan keseluruhan anggota populasi, karena untuk mengeneralisasikannya cukup diwakili oleh sebagian anggota populasi yang disebut sampel (Cooper dan Schindler, 2006). berikut :

Penentuan jumlah sampel menggunakan rumus Slovin (Suliyanto, 2006: 100) sebagai

$$
n=\frac{N}{N(e)^{2}+1}
$$

Keterangan :

$$
\begin{aligned}
& \mathrm{N}=\text { Ukuran populasi } \\
& \mathrm{n}=\text { Ukuran sampel } \\
& e=\text { Persentase kelonggaran ketelitian karena kesalahan pengambilan sampel }
\end{aligned}
$$

Dengan menggunakan tingkat kelonggaran pengambilan sampel sebesar 7,5\%, maka jumlah pegawai yang menjadikan sampel minimal yang diambil dapat dicari sebagai berikut : 


\section{Jurnal Bisnis dan Kajian Strategi Manajemen}

Volume 2 Nomor 2, 2018

ISSN : 2614-2147

http://jurnal.utu.ac.id/jbkan

$$
n=\frac{202}{202(0,075)^{2}+1}=\frac{202}{2.13625}=94.5582
$$

Jadi $n=94,5582$ dibulatkan menjadi 95 responden

Dengan demikian jumlah sampel penelitian adalah sebanyak 95 responden/dosen.

Karena jumlah sub populasinya dikhawatirkan bahwa informasi hanya dari beberapa anggota tingkat atas dan tingkat menengah tidak mencermikan bagaimana semua anggota pada tingkat tersebut merespon, sehingga peneliti memutuskan untuk menggunakan prosedur pengambilan jumlah sampel populasinya menggunakan prosedur acak berstrata atau Proportional Stratified Random Sampling (Sakaran, 2006:131). Untuk menentukan besarnya sampel pada masing-masing satuan kerja dapat dilakukan dengan rumus alokasi proporsional (Sanusi, 2003) sebagai berikut:

$$
\mathrm{Ni}=\mathrm{Ni} / \mathbf{N} \times \mathbf{n}
$$

Sampel sebanyak 95 orang dosen yang aktif mengajar selanjutnya dialokasikan sebagai berikut:

Tabel 3.1

Perincian Jumlah Populasi dan Sampel

\begin{tabular}{|c|l|c|c|c|}
\hline \multirow{2}{*}{ No } & \multirow{2}{*}{$\begin{array}{c}\text { Jabatan } \\
\text { Fungsional }\end{array}$} & \multirow{2}{*}{$\begin{array}{c}\text { Populasi } \\
\text { (orang) }\end{array}$} & Perhitungan & \multirow{2}{*}{ Jumlah Sampel } \\
\cline { 4 - 5 } & & & (Ni/N X n) & \\
\hline 1 & Asisten Ahli & 38 & $38 / 202$ X 95 & 18 \\
\hline 2 & Lektor & 90 & $90 / 202$ X 95 & 42 \\
\hline 3 & Lektor Kepala & 64 & $64 / 202$ X 95 & 30 \\
\hline 4 & Guru Besar & 10 & $10 / 202$ X 95 & 5 \\
\hline \multicolumn{2}{|l|}{ Jumlah } & $\mathbf{2 0 2}$ & & $\mathbf{9 5}$ \\
\hline
\end{tabular}

Tabel data dibuat oleh peneliti berdasarkan DUK Dosen Fakultas Pertanian 2013

\section{Skala Pengukuran}

Dalam kuisioner responden diminta untuk menyatakan tingkat persetujuan mengikuti skala pengukuran yang digunakan dalam penelitian ini yaitu dengan menggunakan skala likert. Skala likert adalah skala yang dirancang untuk memungkinkan responden menjawab berbagai tingkatan pertanyaan pada setiap butir yang menggunakan produk atau jasa. Dalam skala likert, jawaban yang mendukung pertanyaan diberi skor yang tinggi sedangkan untuk jawaban yang tidak atau kurang mendukung diberi skor rendah dan satu pilihan dinilai (score) dengan jarak interval 1 (Sugiyono, 2009).

Penentuan nilai skala likert dengan menggunakan lima tingkatan jawaban yang dapat dilihat dari tabel berikut ini : 


\section{Jurnal Bisnis dan Kajian Strategi Manajemen}

\section{Volume 2 Nomor 2, 2018}

ISSN : 2614-2147

http://jurnal.utu.ac.id/jbkan

\begin{tabular}{|c|c|c|c|c|}
\hline & & $\begin{array}{r}\text { Tabel } 3 \\
\text { Instrumen Ska }\end{array}$ & & \\
\hline $\begin{array}{r}\text { Sangat } \\
\text { Tidak Setuju }\end{array}$ & Setuju & $\begin{array}{r}\text { Tidak } \\
\text { Berpendapat }\end{array}$ & Setuju & $\begin{array}{l}\text { Sangat } \\
\text { Setuju }\end{array}$ \\
\hline 1 & 2 & 3 & 4 & 5 \\
\hline
\end{tabular}

\section{Hasil dan Kesimpulan}

Hasil pengujian hipotesis 1 menunjukkan terdapatnya pengaruh Pemberdayaan Psikologis terhadap Kreativitas. Hasil penelitian tersebut didukung oleh penelitian terdahulu yang dilakukan oleh Spreitzer (1995) Pemberdayaan merupakan suatu teknik menajemen yang digunakan untuk meningkatkan efektivitas organisasi, pemberdayaan dipercaya mampu menumbuhkan kreativitas. Pemberdayaan Psikologi berpengaruh positif terhadap kreativitas dimana ketika seorang karyawan merasakan bahwa pekerjaannya bermakna dan secara pribadi penting, karyawan akan menghabiskan lebih banyak upaya untuk memahami masalah dari berbagai perspektif, mencari solusi dengan menggunakan berbagai informasi dari berbagai sumber, dan menghasilkan sejumlah alternatif dari berbagai sumber informasi (Gilson \& Shalley, 2004; Jabiri, 1991). Selain itu, ketika seorang karyawan percaya bahwa ia memiliki kemampuan untuk melakukan tugas dengan sukses, menentuan nasib sendiri atas pelaksanaan pekerjaannya, dan dapat membentuk hasil yang diinginkan melalui apa yang dia lakukan, karyawan cenderung fokus pada ide atau masalah lebih lama dan lebih continue (Deci \& Ryan, 1991; Spreitzer, 1995). Seperti seorang karyawan juga lebih mungkin untuk mengambil risiko , menjelajahi jalur kognitif baru, dan main-main dengan ide-ide (Amabile et al, 1996)

Hal seperti inilah yang dibutuhkan oleh Dosen di Fakultas Pertanian Universitas Syiah Kuala, mereka di beri kepercayaan dan kebebasan dalam melakuakn tugasnya sehingga mereka punya ruang untuk mengekspresikan ide-idenya yang ada dalam diri mereka dimana ide-ide tersebut akan mempengaruhi pekerjaan dan penyelesaian tugas mereka.

Pengujian hipotesis 2 menunjukkan bahwa Pemberdayaan Psikologis berpengaruh terhadap Motivasi Intrinsik dimana Pemberdayaan menjadi sebuah upaya untuk meningkatkan motivasi intrinsik yang melibatkan kondisi umum dari seorang individu, berkaitan langsung dengan tugas, yang dapat menciptakan motivasi dan kepuasan (Thomas dan Velthouse, 1990). Ketika seorang karyawan mulai merasa di percayai, di beritaggungjawab lebih dan di hargai maka saat itu diamulai merasa ada dorongan dalam dirinya untuk melakukakn dan menyelesaikan tugasnya.

Pemberdayaan Psikologis yang didapatkan oleh dosen di Fakultas Pertanian telah memberi dampak positif terhadap perkembangan motivasi intinsik mereka, ini telihat jelas pada keinginan dan motivasi dalam penyelasaian tugas dan peaksanaan misi-misi fakultas. 


\section{Jurnal Bisnis dan Kajian Strategi Manajemen}

\section{Volume 2 Nomor 2, 2018}

ISSN : 2614-2147

http://jurnal.utu.ac.id/jbkan

Pengujian hipotesis 3 menunjukkan bahwa Motivasi Intrinsik berpengaruh terhadap Kreatifitas. Amabile (1983) mengemukakan bahwa Motivasi Intrinsik memainkan peran penting dalam menentukan perilaku yang dapat mempengaruhi Kreatifitas . Hal ini karena motivasi intrinsik membuat perbedaan antara apa yang seseorang dapat lakukan dan apa yang seorang individu akan melakukan (Amabile, 1988: 133). Simon (1967) menunjukkan bahwa fungsi utama dari motivasi intrinsik adalah kontrol perhatian ketika individu secara intrinsik terlibat dalam pekerjaan mereka, mereka lebih mungkin untuk mencurahkan semua perhatian mereka terhadap masalah yang mereka hadapiPengujian ini sesuai dengan apa yang disebutkan oleh (Oldham dan Cummings 1996) untuk menjadi kreatif, karyawan harus cukup tertarik pada masalah tertentu dan mencari cara untuk memecahkan atau mencapainya disini motivasi berfungsi untuk mengontrol perhatian masalah tugas kreatif karyawan dengan mencurahkan isu heuristis (Woodman, Sawyer, dan Griffin 1993). Karyawan yang termotivasi secara intrinsik lebih mungkin untuk mengeksplorasi jalur baru dan mengambil risiko yang lebih bsar (Amabile , Goldfarb , dan Brackfield 1990) . Akibatnya karyawan yang termotivasi secara intrinsik akan lebih bersemangat tentang pekerjaan mereka dan ini meningkatkan kreativitas (Shalley, Zhou dan Oldham 2004).

Kondisi ini yang di alami oleh para dosen di fakultas pertanian, motivasi intrinsik telah membantu mengembangkan kreativitas mereka dalam bekerja dan menyelesaikan tugasnya ketertarikan dalam mencoba berbagai cara untuk meyelesaikan pekerjaan mereka menjadi hal yang sangat berguna demi mewujudkan visi Fakultas Pertanian Universitas Syiah Kuala

Pengujian hipotesis 4 mengatakan bahwa Motivasi Intrinsik memediasi pengaruh Pemberdayaan Psikologis terhadap Kreativitas. Pemberdayaan Psikologis mampu memberi kontribusi penting untuk kreativitas karyawan secara positif dengan mempengaruhi Motivasi Intrinsik karyawan (Amabile, 1996; Spreitzer, 1995) secara konseptual, Motivasi Intrinsik dianggap menjadi Prediktor mapan Kreativitas (Amabile, 1996; Shalley dkk, 2004).

Hal seperti inilah yang harus diperhatikan dan ditingkatkan secara berkesinambungan oleh Fakultas Pertanian Universitas Syiah Kuala guna meningkatkan kreatifitas dengan terus memberikan kepercayaan, tanggungjawab, dorongan dari dalam, semangat dan kebebasan bagi para dosenya dalam melakukan tugas mereka sehingga mereka bisa berekspresi mengeluarkan segenap kemampuan dan ide-ide kreatif mencoba melakukan berbagai cara dan metode tanpa merasa terkekang sehingga usaha mewujudkan cita-cita organisasi menjadi lebih mudah di wujudkan.

\section{Daftar Pustaka}

\section{DAFTAR PUSTAKA}

Alan J. Rowe. 2005. Creative Intelligence: Discovering The Innovative Potential In Ourselves And Others. Bandung. Mizan. Terjemahan

Amabile, T. M. 1979. Effects of external evaluation on artistic creativity. Journal of Personality and Social Psychology, 37: 221-233.

Amabile, T. M. 1983. The social psychology of creativity: A componential conceptualization. Journal of Personality and Social Psychology, 45:357-376. 


\section{Jurnal Bisnis dan Kajian Strategi Manajemen}

Volume 2 Nomor 2, 2018

ISSN : 2614-2147

http://jurnal.utu.ac.id/jbkan

Amabile, T. M. 1985. Motivation and creativity: Effects of motivational orientation on creative writers. Journal of Personality and Social Psychology, 48: 393-399.

Amabile, T. M. 1987. The motivation to be creative. In S. Isaksen (Ed.), Frontiers in creativity: Beyond the basics: 223-254. Buffalo, NY: Bearly.

Amabile, T. M. 1988. A model of creativity and innovation in organizations. In B. M. Staw \& L. L. Cummings (Eds.), Research in organizational behavior, vol. 10: 123-167. Greenwich, CT: JAI Press.

Amabile, T. M. 1993. Motivational synergy: Toward new conceptualizations of intrinsic and extrinsic motivation in the workplace. Human Resource Management Review, 3: $185-201$.

Amabile, T. M. 1996. Creativity in context. Boulder, CO:Westview Press.Gilson, L. \& Shalley, C. E. 2004. A little creativity goes a long way: An examination of teams' engagement increative processes. Journal of Management, 30: 453-470.

Baron, R.M. and Kenny, D.A. 1986. The Moderator-Mediator Variable Distinction In Social Psychological Research: Conceptual, Strategic, And Statistical Considerations. Journal Of Personality And Social Psychology. 51(6): 1173-1182.

Bobbi De Porter \& Mike Hernacki. 2001. Quantum Learning. Membiasakan belajar nyaman dan menyenagkan. Terjemahan Alwiyah Mizan Media Utama, Bandung.

Conger, J.A., dan Kanungo, R.N. 1988. The empowerment process: integrating theory and practice, Academy of Management Review, 13: 417-482.

Clegg, P. 2008. Creativity And Critical Thingking In The Globalised University. Innovations In Education And Teaching International, Vol 5 No, 3.

Chandra, J. 1994. Kreativitas: Bagaimana menanamkan, membangun, dan mengembangkannya. Yogyakarta: Penerbit Kanisius

Craft, A. 2005. Membangun Kreativitas Anak. Depok: Insani Press.

Gilson, L. L., \& Shalley, C. E. 2004. A little creativity goes a long way: An examination of teams' engagement in creative processes. Journal of Management, 30:453-470.

Gitosudarmo, Indriyo dan I Nyoman Sudita. 2000. Perilaku Keorganisasian. Yogyakarta : BPFE.

Gustiyah, Raikan. 2009. Analisis Faktor-faktor yang Mempengaruhi Motivasi Kerja Penyeluhan Perindustrian pada Kantor Perindustrian dan Perdagangan Kota Medan. Tesis. 


\section{Jurnal Bisnis dan Kajian Strategi Manajemen}

Volume 2 Nomor 2, 2018

ISSN : 2614-2147

http://jurnal.utu.ac.id/jbkan

Hasibun, M.S.P. 2005. Organisasi Dan Motivasi; Dasar Peningkatan Produktivitas. Jakarta; PT. Bumi Aksara.

Hurlock, E. B. 1993. Perkembangan Anak Jilid 2. Terjemahan oleh Thandrasa. Jakarta: PT. Erlangga

Kathryn M. Bartol dan Xiaomeng Zhang. 2012. Linking empowerment leadership and employee creativity: The influence of psychological empowerment, intrinsic motivation, and creative process engagement. Academy of Management Journal, Vol. 55, No. 1, 111-130.

Lubart, T. I. 2001. Models of the creative process: Past, present and future. Creativity Research Journal, 13, 295 - 308.

Meyerson, S . L., and K line, T. J. B. 2008. "Psychological and Enviromental Empowerment: A ntecedents and Consequences." Leadership and Organization Development Journal. Vol. 29, No. 5, pp. 444-460.

Mishra, A.K., dan Spreitzer, G.M. 1998. Explaining how survivors respond to downsizing: the roles of trust, empowerment, justice, and work redesign, Academy of Management Review, 23(1) 567-588.

Munandar, S. C. U. 1983. Kreativitas Sebagai Aktualitas Diri: Suatu Tinjauan Psikologis. Kreativitas: Kumpulan 12 Makalah. Jakarta: PT. Dian Rakyat.

Munandar, S. C. U. 2009. Kreativitas Sepanjang Masa. Jakarta: Pustaka Sinar Harapan.

Munandar, S. C. U. 1985. Mengembangkan Bakat dan Kerativitas Anak Sekolah. Jakarta: PT. Gramedia.

Munandar, S. C. U. 1999. Kreativitas dan Keberbakatan: Strategi Mewujudkan Potensi Kreatif dan Bakat. Cetakan ke-3. Jakarta: PT. Gramedia.

Nawawi, H., 2002. Manajemen Sumber Daya Manusia Untuk Bisnis Yang Kompetitif. Yogyakarta: Gadjah Mada University Press.

Reiter-Palmon, R., \& Illies, J. J. 2004. Leadership and creativity: Understanding leadership from a creative problem solving perspective. Leadership Quarterly, 15: 55-77.

Robbins, Stepen.2007. Perilaku Organisasi. Terjemahan: Benyamin Molan. New Jersey Prentice Hall, Inc.

Runco, M. A. 2004. Creativity; Annual Review Of Psychology. [NLM-MEDLINE] 55, 657.

Sadarusman, Eka. 2004. Pemberdayaan: Sebuah Usaha Memotivasi Karyawan. Jurnal Fokus Ekonomi,Vol. 3, No.2,Agustus. 


\section{Jurnal Bisnis dan Kajian Strategi Manajemen}

Volume 2 Nomor 2, 2018

ISSN : 2614-2147

http://jurnal.utu.ac.id/jbkan

Sarwoto. 1986. Dasar-dasar Organisasi dan Manajemen. Cetakan keenam. Jakarta: Ghalia Indonesia.

Sekaran, Uma. 2006. Metodologi Penelitian Untuk Bisnis. Edisi 4. Jakarta:Salemba Empat.

Siagian, Sondang P. 2002. Kiat meningkatkan Produktivitas Kerja. Cetakan Pertama. Jakarta : Rineka Cipta.

Sugiarto, Siagian D. Sunaryanto, L.T., Oetomo, D.S. 2003. Teknik Sampling. Jakarta: PT. Gramedia Pustaka Utama.

Syahu Sugian. 2006. Kamus Manajemen (Mutu). Jakarta . PT Gramedia Pustaka Utama.

Syukri, R. M., \& Zulkarnain. 2005. Asertivitas dan Kreativitas pada Karyawan yang Bekerja di Multi Level Marketing. Jurnal Psikologia Vol. 1., No.2. USU Press

Undang-Undang No. 20 Tahun 2003 Bab II Pasal 3

Wibowo, 2007. Manajemen Kinerja. Jakarta: PT Raja Grafindo Persada

Wijayanto, 2003. Sumber Daya Manusia, Kreativitas, Inovasi: PengetahuannSebagai Sumber Keunggulan Kompettitif Berkesinambungan. Fokus Ekonomi. Vol 2 No. 2, 123-135

Wijono, S. 2002. Hubungan Antara Motivasi Kerja dengan prestasi kerja di sebuah perusahaan. Jurnal Psikologi. Vol . 13, No. 2, h. 30-41.

Winardi. 1991. Kreativitas Dan Tekknik-Teknik Pemikiran Kreatif Dalam Bidang Manajemen. Bandung: Citra Aditya.

Zulkarnain. 2002. Hubungan Kontrol Diri Dengan Kreativitas Pekerja. USU Digital ibrary. [On-Line]. Available FTP:

http://duniapsikologi.dagdigdug.com/files/2008/12/kontrol-diri-dan-kreativitas-

kerja.pdf. Tanggal akses 24 September 2013 